\title{
The Effect of Physical Activities and Smoking Habits toward Incidence of Stroke on Patients in Santa Elisabeth Hospital
}

\author{
Renova Suryani Panjaitan ${ }^{1}$, Fazidah Aguslina Siregar ${ }^{2}$, Albiner Siagian $^{2}$ \\ ${ }^{1}$ Master Student of Public Health, Universitas Sumatera Utara, Medan, Indonesia \\ ${ }^{2}$ Lecturer in Faculty of Public Health, Universitas Sumatera Utara, Medan, Indonesia \\ Email: renovasuryani@gmail.com
}

\begin{abstract}
:
Stroke is an important health problem in the world because stroke shows increased pain. In Indonesia, there are 500,000 people who experience strokes each year among 125,000 people die and others experience mild and severe disability. The purpose of this study is to analyze the effect of physical activities and smoking habits toward incidence of stroke on inpatients at Santa Elisabeth Hospital, Medan. This research is an observational analytic with a case control study design. Subjects consisted of cases and controls with a ratio of 1: 1 totaling 106 people namely 53 cases and 53 controls. Data collection uses interviews and questionnaires. Data analysis using simple logistic regression test. Simple logistic regression test results found that there is a significant influence between physical activity $(p=0.014 ; O R=2.828,95 \%$ CI 1,220-6,553) and smoking habits $(p=$ $0.001 ; O R=3,720,95 \%$ CI 1,668-8,297) on the incidence stroke. It is recommended to do physical activity with adequate body movements and exercise and stop smoking.

Keywords:

physical activities; smoking habits; stroke
\end{abstract}

\section{Introduction}

Stroke is an important health problem in the world today because stroke shows increased pain. Stroke occurs in developing countries and developed countries. Stroke as a sudden brain disorder that can cause circulatory disorders and result in physical disorders or disabilities in patients. Stroke becomes a dangerous disease and requires rapid treatment. Stroke symptoms make weakness in parts of the body, face, legs or arms (WHO, 2017).

According to the 2017 Global Burden Report every year, 15 million people worldwide suffer a stroke (WHO, 2017). The American Stroke Association (2016) reports that strokes around the world continue to increase. Stroke as the main cause of disability and death in the world. Deaths are caused by stroke which is 11.8 percent of the total deaths in the world. According to WHO in 2015, an estimated 20 million people will die of a stroke. In 2015 around 795,000 people in America suffered strokes per year, around 610,000 were the first strokes and 185,000 were recurrent strokes (AHA, 2016).

According to the South East Asian Medical Information Center (SEAMIC) that stroke is the leading cause of death in Southeast Asian countries (ASEAN). The highest mortality rates occur in Indonesia, then the Philippines, Singapore, Brunei Darussalam and Malaysia.

In Indonesia, there are 500,000 people who experience strokes every year, between 2.5 percent, 125,000 people die and others suffer from mild and severe disability. Of the total strokes, 80 percent are ischemic strokes and only 20 percent are hemorrhagic strokes (Yastroki, 2012).

Based on Riskesdas (2013) it is known that the prevalence of stroke from the diagnosis of health workers is highest in South Sulawesi at 17.9 percent. While in the Province of North 
Sumatra, the prevalence of stroke was 6.3 percent. The prevalence of stroke patients in the group diagnosed by health workers and symptoms increased a lot according to age, which was highest at the age of more than 75 years (43\%). The prevalence of stroke tends to be higher in the group that has low education. In urban areas higher than rural areas, and have a higher tendency in the population groups of people who do not work, this can occur due to lack of knowledge about good eating patterns (Riskesdas, 2013).

Research conducted by Maulidiyah, et al in 2014 at the Soedarso Regional Hospital in Pontianak obtained a significant relationship between eating patterns $(\mathrm{OR}=3.266)$, smoking $(\mathrm{OR}=2.883)$, alcohol consumption $(\mathrm{OR}=6.155)$ from stroke. Research conducted by Perawaty, et al in 2014 in the city of Palangkaraya obtained a significant relationship to eating patterns, namely consumption of processed foods, less consumption of fruit, less consumption of fish, hypertension and lack of physical activity $(\mathrm{OR}=3.46)$. Likewise, a study conducted by Burhanuddin et al in 2013 in Makassar City in early adulthood (18-40 years) obtained smoking as a significant risk factor with the incidence of stroke (OR value $=2.68)$, a history of diabetes and a history of hypertension.

Lifestyle that does not maintain health is a risk factor for hypertension and diabetes mellitus that affects the incidence of stroke. Based on the research results of Farra Aulia et al regarding the incidence of ischemic stroke in RSUD DR. Moewardi Surakarta in 2010 found that there was a significant relationship between diabetes mellitus and the incidence of ischemic stroke $(\mathrm{OR}=3.8)$. Research by Pratiwi et al in 2017 in the Pangandaran community found stroke risk factors through checking blood sugar, cholesterol, uric acid and lifestyle. It was found that the majority of Pangandaran Village people had stroke risk factors such as high cholesterol levels $(74.7 \%)$, lack of exercise activities $(73.6 \%)$ and a history of hypertension $(60.9 \%)$.

Based on preliminary surveys conducted at the Santa Elisabeth Hospital in Medan according to data from medical records in 2017, 323 cases of inpatient stroke were identified and in 2018 there were 335 cases. From 335 stroke sufferers it is known that the number of male and female patients is approximately equal, namely 168 female and 167 male. Age of majority sufferers over 45 years. In 2018 stroke was ranked seventh in the list of the 10 biggest diseases inpatient at the Santa Elisabeth Hospital in Medan.

Santa Elisabeth Hospital Medan is one of the hospitals in North Sumatra Province with a class B hospital. This hospital is a reference for many diseases from various regions in North Sumatra such as cases of stroke, diabetes mellitus, hypertension, respiratory infections and diseases the other. This hospital has provided good services to both inpatient and outpatient patients. The Santa Elisabeth Hospital in Medan already has good management and programs for the treatment and recovery of stroke patients by providing physiotherapy services to serve stroke patients who are hospitalized and outpatient in this hospital. Physiotherapy room staff have also provided good service and counseling for stroke patients to always maintain their health for the prevention of recurrent strokes later in the day. Making efforts to prevent the disease from getting worse, the officer recommends the sufferer to change and maintain healthy and balanced eating habits and reduce foods that contain high cholesterol, fat and carbohydrates, reduce the consumption of lots of salt, follow the doctor's advice to be diligent in monitoring the Santa Elisabeth puzzle. Medan is known to have a high incidence of stroke. This stroke is a result of brain blood circulation disorders that are influenced by many irreversible risk factors such as age, gender, and family history, while factors that can be changed such as lifestyle include diet, physical activity, smoking and alcohol 
consumption.

Based on direct interviews conducted with 10 stroke patients who had been hospitalized in 2018 at the Santa Elisabet Hospital in Medan who were outpatient, obtained five people with less physical activity, and rarely exercising, four had smoked. The majority of patients do not consume alcohol. The majority of stroke sufferers answered that they did not know about how to live a healthy lifestyle.

\section{Research Method}

The purpose of this study was to analyze the effect of physical activity and smoking habits on the incidence of stroke in inpatients at Santa Elisabeth Hospital, Medan. This type of research is an observational analytic epidemiological study with case control study design.

The case population in this study were all patients diagnosed by doctors suffering from stroke who were hospitalized in Santa Elisabeth Hospital Medan as many as 335 cases, including patients who had recurrent strokes who were hospitalized. The control population in this study were all patients diagnosed by doctors who did not suffer a stroke in the general surgery department at Santa Elisabeth Hospital, Medan. The number of samples for the case were 53 patients who had a stroke and the control group were 53 patients who did not stroke. Comparison of cases and controls is 1: 1 so the total sample of cases and controls is 106 people, between cases and controls are not matching (unmatching).

Variables in the study consisted of physical activity, smoking habits and the incidence of stroke. Data collection is done by conducting interviews and filling out questionnaires. Statistical analysis was performed using a simple logistic regression statistical test.

\section{Discussion}

\subsection{Overview of Physical Activity and Smoking Habits}

The results showed that respondents in the physical activity case group were less / lighter by 41 people $(77.4 \%)$ and in the control group by 29 people (54.7\%). While respondents with sufficient physical activity in the case group were 12 people $(22.6 \%)$ and in the control group were 24 people $(45.3 \%)$. Information that respondents in the case group smoked 36 people $(68 \%)$ with smoking habits $\geq 20$ cigarettes there were 6 people $(11.3 \%)$ and smoking $<20$ cigarettes there were 30 people $(56.7 \%)$ and in the control group amounted to 24 people $(45.3 \%)$ with smoking habit $\geq 20$ cigarettes there were 4 people $(7.5 \%)$ and $<20$ cigarettes there were 20 people $(37.8 \%)$. While respondents who did not smoke in the case group were 17 people (32\%) and 29 controls (54.7\%).

Table 1

\begin{tabular}{ccccc}
\hline \multirow{2}{*}{ Variable } & \multicolumn{2}{c}{ Case } & \multicolumn{2}{c}{ Control } \\
\cline { 2 - 5 } & n & \% & n & \% \\
\hline Physical Activities & & & & \\
Kurang & 41 & 77,4 & 29 & 54,7 \\
Cukup & 12 & 22,6 & 24 & 45,3 \\
$\quad$ Total & $\mathbf{5 3}$ & $\mathbf{1 0 0}$ & $\mathbf{5 3}$ & $\mathbf{1 0 0}$ \\
\hline Smoking Habits & & & & \\
$\geq 20$ cigarettes & 6 & 11,3 & 4 & 7,5 \\
$<20$ cigarettes & 30 & 56,7 & 20 & 37,8
\end{tabular}




\begin{tabular}{ccccc} 
Not smoking & 17 & 32,0 & 29 & 54,7 \\
Total & $\mathbf{5 3}$ & $\mathbf{1 0 0}$ & $\mathbf{5 3}$ & $\mathbf{1 0 0}$ \\
\hline
\end{tabular}

\subsection{Effects of Physical Activity and Smoking Habits on Stroke Events}

Simple logistic regression test results show that the OR value of physical activity OR value $=2.828(95 \%$ CI 1,220-6,553 $p=0.014)$ this means that people who have less physical activity have a risk of 2.828 times greater stroke than those who have enough physical activity.

Smoking habits obtained OR values $=2.559(95 \%$ CI 1.161-5.642 $\mathrm{p}$ value $=0.019)$ this means that people who have smoking habits have a 2.559 times greater risk of stroke than those who do not have smoking habits.

Table 2

\begin{tabular}{|c|c|c|c|c|}
\hline \multirow{2}{*}{ Variable } & \multicolumn{2}{|c|}{ Case } & \multicolumn{2}{|c|}{ Control } \\
\hline & $\mathbf{n}$ & $\%$ & $\mathrm{n}$ & $\%$ \\
\hline \multicolumn{5}{|c|}{ Physical Activities } \\
\hline Risk & 41 & 77,4 & 29 & 54,7 \\
\hline No Risk & 12 & 22,6 & 24 & 45,3 \\
\hline \multicolumn{5}{|c|}{$\mathrm{P}=0,014 ; \mathrm{OR}=2,828(95 \%$ CI $1,220=6,553)$} \\
\hline \multicolumn{5}{|c|}{ Smoking Habits } \\
\hline Risk & 36 & 68,0 & 24 & 45,3 \\
\hline No Risk & 17 & 32,0 & 29 & 54,7 \\
\hline
\end{tabular}

\subsection{Discussion}

a. The Effect of Physical Activity on the Incidence of Stroke in Santa Elisabeth Hospital Medan

Statistical test results with bivariate analysis using simple logistic regression test obtained a relationship between physical activity and the incidence of stroke with a value of OR $=2.828(95 \%$ CI 1,220-6,553 $\mathrm{p}=0.014)$, this means that people who have less physical activity have a risk of 2.828 times more likely to have a stroke than enough physical activity.

The results of this study are in line with research conducted by Perawaty, et al in 2014 in the incidence of stroke in RSUD dr. Doris Sylvanus of Palangkaraya City stated that there was a significant association of less physical activity $(\mathrm{OR}=3.46)$ which means that people who had less physical activity had a 3.46 times greater risk of stroke than those with sufficient physical activity.

The results of research with mild daily activities due to work, lack of movement, lack of exercise and more activities to sit everyday. So that physical activity can be done by diligently exercising lightly every day.

Generally physical activity is synonymous with sports activities, walking, jogging, swimming, aerobics and riding a bicycle is a way to live a healthy life. When doing this process requires energy until the calorie burning occurs, but not all are always synonymous with exercise because routine activities that are usually done when we work is an activity by members of the body (Irianto, 2007). Therefore work is also a physical activity. Lack of exercise, including risk factors that influence the incidence of stroke. Exercise activities well is about half an hour / 30 minutes every day can reduce the risk factors for stroke (Junaidi, 2011). 
In this study had less physical activity because in working daily as an entrepreneur and private employees more sitting and less movement. Lack of physical activity ie lack of exercise and prolonged sitting are the fourth risk of causing death worldwide, so sitting too long is as dangerous as cigarettes that cause heart disease. Compared to obesity, sitting too long doubled cause heart disease or death. Obtained by six out of ten adults in Indonesia sitting continuously for more than three hours per day, this is a risk factor for stroke (Riskesdas 2013).

\section{b. The Influence of Smoking Habits on the Incidence of Stroke in Santa Elisabeth Hospital Medan}

Statistical test results using a simple logistic regression test showed there was a relationship between smoking habits variables with the incidence of stroke with a value of OR $=2.559(95 \%$ CI 1.161-6.5642 $p=0.019)$ this means that people who have the habit of smoking have a risk of 2.559 times greater stroke than those who do not have a smoking habit.

This research is in line with Maulidiyah, et al (2014) at Soedarso Hospital Pontianak obtained a significant relationship between smoking habits with an OR $=2.883$ which means that people who have smoking habits have a risk of 2.883 times greater stroke than those who do not smoke.

This study is in line with Patricia, et al (2015) at Prof. RSUP Dr. RD Kandou Manado smoking increases the risk of stroke almost twice, and passive smokers get a stroke 1.2 times greater.

\section{Conclusion}

Physical activity and smoking habits affect the incidence of stroke. People who have less physical activities have a risk of 2,828 times greater stroke than those who have enough physical activities, while people who have a smoking habit have a risk of 2.559 times more likely to have a stroke than those who do not have a smoking habit. Need to do physical activities with enough body movements and exercise and stop smoking.

\section{References}

American Heart Association (AHA), (2015). Heart disease and stroke statistics. AHA

Arisma, (2010). Gizi dalam daur kehidupan. Edisi Kedua. Jakarta: Penerbit Buku Kedokteran EGC

Badan Penelitian dan Pengembangan Kesehatan. (2013). Riset kesehatan dasar (Riskesdas 2013) Jakarta Kementerian Kesehatan RI

Goldszmitdt \& Louis R., (2011). Esensial stroke, Jakarta : Buku Kedokteran EGC

Irianto, P. (2007). Panduan gizi lengkap keluarga dan olahragawan. Yogyakarta : Penerbit Andi

Junaidi, I. (2011). Stroke, waspadai ancamannya. Yogyakarta : Penerbit Andi

Maulidiyah, I., Nasip, M., \& Marleniwaty. (2015). Faktor-faktor yang berhubungan dengan kejadian stroke Iskemik pada pasien rawat inap di RSUD Soedarso Pontianak ( Disertasi, Universitas Muhammadiyah Pontianak.) Diakses dari http://repository.unmuhpnk.ac.id/id/eprint/14 
Perawaty, P., Dahlan, P., \& Astuti, H. (2016). Pola makan dan hubungannya dengan kejadian stroke di RSUD dr. Doris Sylvanus Palangka Raya. Jurnal Gizi dan Dietetik Indonesia Indonesian Journal of Nutrition and Dietetics, 2(2), 51-61.

Yayasan Stroke Indonesia, Yastroki tangani masalah stroke di Indonesia.2012 (15 Februari 2019) http:www.yastroki.or.id/readphp?id=20

WHO. Stroke Association Annual Report 2017 from http: www.who.int/cardiovascular disease/en/cvd atlas 15 burden stroke.pdf 